\title{
A CONVENIENT SYNTHESIS AND CYTOTOXIC ACTIVITY OF 3-ARYL-5-PENTYL-1,2,4-OXADIAZOLES FROM CARBOXYLIC ACID ESTERS AND ARYLAMIDOXIMES UNDER SOLVENT-FREE CONDITIONS
}

\author{
CARLOS JONNATAN PIMENTEL BARROS, ${ }^{a}$ ZILYANE CARDOSO DE SOUZA, ${ }^{a}$ JUCLEITON JOSÉ RUFINO DE \\ FREITAS, ${ }^{a}$ PAULO BRUNO NORBERTO DA SILVA, ${ }^{b}$ GARDENIA CARMEN GADELHA MILITÃO, ${ }^{b, c}$ TERESINHA \\ GONÇALVES DA SILVA, ${ }^{c}$ JULIANO CARLO RUFINO FREITAS, ${ }^{a, d, *}$ JOÃO RUFINO DE FREITAS FILHO ${ }^{a, *}$
}

\begin{abstract}
${ }^{a}$ Departamento de Química, Universidade Federal Rural de Pernambuco, Av. Dom Manoel de Medeiros, s/n, 52171-900, Recife, PE, Brazil. ${ }^{b}$ Departamento de Fisiologia e Farmacologia, Universidade Federal de Pernambuco, Rua Nelson Chaves, s/n, 50670-901, Recife, PE, Brazil. 'Departamento de Antibióticos, Universidade Federal de Pernambuco, Av. Artur de Sá, s/n, 50670-901, Recife, PE, Brazil. ${ }^{d}$ Centro de Educação e Saúde, Universidade Federal de Campina Grande, Olho D'agua da Bica, s/n, 58175-000, Cuité, PB, Brazil.
\end{abstract} (Received: August 14, 2013 - Accepted: December 14, 2013)

\begin{abstract}
The synthesis of 3-aryl-5-pentyl-1,2,4-oxadiazoles from carboxylic acid esters and arylamidoximes in the presence of potassium carbonate is described. The reaction was carried out in a microwave oven without any solvent in much shorter time and in good yields. The structures of the synthesized compounds were elucidated using IR, ${ }^{1} \mathrm{H}$ and ${ }^{13} \mathrm{C}$ NMR spectroscopy and elemental analysis and their antiproliferative activities was evaluated against three different human cell lines.
\end{abstract}

Keywords: 1,2,4-Oxadiazoles; Amidoximes; Microwave oven; Cytotoxic Activity.

\section{INTRODUCTION}

The 1,2,4-oxadiazoles (fig. 1) represent a class of heterocyclics with a wide variety of biological activities, especially anti-inflamatory, $1,2,3$ antitumor ${ }^{4,5}$ and antifungal activities. ${ }^{6}$ Biologically relevant compounds containing the 1,2,4-oxadiazole moiety also include HIV integrase inhibitors, ${ }^{7}$ antituberculostatic agents ${ }^{8}$ and antikinetoplastid agents. ${ }^{9}$ They are also reported as inhibitors of tyrosine kinase,$^{10}$ bacterial and human DNA topoisomerases, ${ }^{11}$ and human neutrophil elastase. ${ }^{12}$ Many 1,2,4-oxadiazoles 3,5-disubstituted have been shown to be bioactive compounds. In the literature it is possible to find compounds containing the 1,2,4-oxadiazole ring with differing activities (Figure 1), for example: anti-diabetic (a), ${ }^{13}$ anti-inflammatory (b),${ }^{3}$ antitumor (c) ${ }^{14}$ anti-cancer $(\mathbf{d})^{15}$ and larvicidal and fungicide (e). ${ }^{16}$

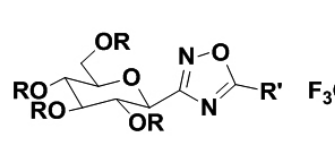

(a)

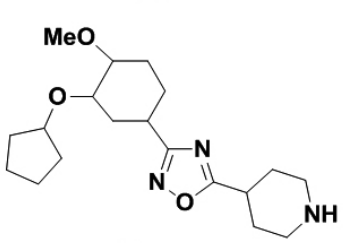

(e)

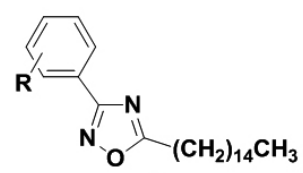

(b)

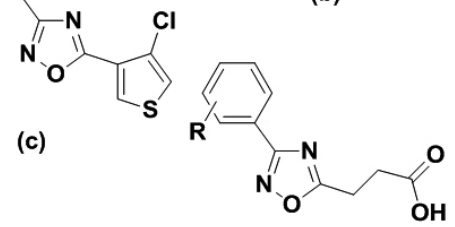

(d)
Figure 1. Examples of biologically active 1,2,4-oxadiazoles.

Generally, 1,2,4-oxadiazoles are synthesized by cyclodehydration of $\mathrm{O}$-acylamidoximes, promoted by either heat or by bases, such as $\mathrm{NaH}$, NaOEt or pyridine. ${ }^{17}$ The use of tetrabutylammonium fluoride (TBAF) as an activator to promote the cyclization of $O$-acylamidoximes has been reported.$^{18}$ Historically, the preferred method of obtaining $O$-acylamidoximes is through the reaction of amidoximes with activated carboxylic acid derivatives or with carboxylic acids in the presence of a coupling reagent, such as dicyclohexylcarbodiimide (DCC), ${ }^{19,20,21}$ 1-[3-(dimethylamino)propyl]3-ethylcarbodiimide (EDC), ${ }^{11,20,22}$ 2-(dimethylamino)isopropyl chloride (DIC)/HOBt, ${ }^{11}$ bis-(2-oxo-3-oxazolidinyl)phosphinic chloride (BOP-Cl), ${ }^{20}$ 2-(1H-benzotriazole-1-yl)-1,1,3,3-tetramethyluronium tetrafluoroborate (TBTU), ${ }^{23}$ or 1,1 '-carbonyldiimidazole (CDI) ${ }^{20,24}$ However, these methods have several drawbacks. Acid chlorides are very toxic and reactive chemicals and thus are hard to store and handle, and only a few acid chlorides are readily available. Other recently reported methods to obtain 1,2,4-oxadiazoles include the use of PTSA- $\mathrm{ZnCl}_{2}$ as an efficient and catalytic reagent for the synthesis of 1,2,4-oxadiazoles 3,5-disubstituted from amidoximes and organic nitriles. ${ }^{25}$ These reactions, however, require long reaction times, high temperatures, produce by-products and, in general, the products obtained are difficult to purify. ${ }^{26,27}$ Microwave irradiation, an efficient and innocuous technique for reagent activation in the synthesis of organic compounds, and in particular heterocyclic compounds, has been applied with success, and was able to generate products in good to excellent yields. ${ }^{28,29,30,31}$

The use of microwave irradiation in organic chemistry has being widely explored over the last few years. ${ }^{32}$ Two of the main advantages of this technology are the potential for dramatically shortened reaction times and access to reaction conditions that are not attainable with conventional thermal heating. ${ }^{23}$

In this report, we describe the synthesis and cytotoxic activity of six 3-aryl5-pentyl-1,2,4-oxadiazoles 3a-f under solvent-free conditions employing an unmodified domestic microwave oven. To the best of our awareness, this contribution reports a simple and straightforward synthesis of 1,2,4-oxadiazoles having a alkyl chain attached at C-5 in good yields. Conventionally, syntheses of this class of compounds have been achieved in 5-18h. . $^{30,33}$

\section{EXPERIMENTAL}

General consideration:

All commercially available reagents were used directly without purification unless otherwise stated. All the solvents used in reactions were distilled for purity. IR spectra were recorded as $\mathrm{KBr}$ films on a Brucker IFFS66 series Fourier transform spectrophotometer. ${ }^{1} \mathrm{H}$ and ${ }^{13} \mathrm{C}$ NMR spectra were recorded on a Bruker DPX 400 spectrometer at $400 \mathrm{MHz}$ and $100 \mathrm{MHz}$, respectively, using $\mathrm{CDCl}_{3}$ as solvent and $\mathrm{Me}_{4} \mathrm{Si}$ as the internal standard. Chemical shifts are reported in ppm. Coupling constants are reported in Hz. Thin Layer Chromatography (TLC) was performed using Merck ${ }^{\circledR}$ Silica gel $60 \mathrm{~F}_{254}$ Plates. Microwave reactions were performed in a domestic microwave oven, SANYO, model EM-300B $(220 \mathrm{~V} ; 650 \mathrm{~W} / 2450 \mathrm{MHz})$. The precise heating area in the oven was located, and the experiments were repeated several times. ${ }^{29}$

General Procedure for the Synthesis of ethyl hexanoate (2)

Hexanoic acid $(7.00 \mathrm{~g}, 60.3 \mathrm{mmol})$, ethanol $(65 \mathrm{~mL})$ and sulfuric acid $(0.70$ $\mathrm{mL}$ ), were refluxed for 4 hours. The progress of the reaction was monitored by TLC on $0.2 \mathrm{~mm}$ precoated silica gel $60 \mathrm{~F}_{254}$ plates (E. Merck). After the reaction, the alcohol in excess was removed under reduced pressure and the residue was extracted with ethyl acetate. The ether extract was washed with a solution of sodium bicarbonate and subsequently with distilled water, dried over anhydrous sodium sulfate and concentrated in vacuo to yield the crude product, which was purified by column chromatography silica gel 60 (Merck ${ }^{\circledR} 70-230$ mesh) using 9:1 hexanes/EtOAc as eluent, to give the desired carboxylic ester 
$(6.77 \mathrm{~g}, 78 \%$ yield $) . \mathrm{IR}(\mathrm{KBr}) v_{\mathrm{N}} 2959,2869,1738,1462,1373,1245,1100$ $1035,735 \mathrm{~cm}^{-1} .{ }^{1} \mathrm{H}$ NMR $\left(400 \mathrm{MHz}, \mathrm{CDCl}_{3}\right): \delta 4.13(q, J=6.8 \mathrm{~Hz}, 2 \mathrm{H}$ $\left.\mathrm{OCH}_{2} \mathrm{CH}_{3}\right), 2,29\left(t, J=7.2 \mathrm{~Hz}, 2 \mathrm{H}, \mathrm{CH}_{2} \mathrm{CO}\right), 1.66-1.59\left(\mathrm{~m}, 2 \mathrm{H}, \mathrm{CH}_{2} \mathrm{CH}_{2} \mathrm{CO}\right)$, $1.35-1.28\left(\mathrm{~m}, 4 \mathrm{H},\left(\mathrm{CH}_{2}\right)_{2} \mathrm{CH}_{3}\right), 1.26\left(\mathrm{t}, J=6.8 \mathrm{~Hz}, 3 \mathrm{H}, \mathrm{OCH}_{2} \mathrm{CH}_{3}\right), 0.89(\mathrm{t}, \mathrm{J}=$ $\left.7.2 \mathrm{~Hz}, 3 \mathrm{H},\left(\mathrm{CH}_{2}\right)_{2} \mathrm{CH}_{3}\right) .{ }^{13} \mathrm{C} \mathrm{NMR}\left(100 \mathrm{MHz},\left(\mathrm{CDCl}_{3}\right): \delta 173.8,60.1,34.3\right.$, $31.3,24.6,22.3,14.2,13.8$. The spectroscopic data of synthesized compound match with the reported values in the literature. ${ }^{34}$

General Procedure for the Synthesis of 3-aryl -5-pentyl-1,2,4oxadiazoles (3a-f)

A mixture of ethyl hexanoate $2(0.22 \mathrm{~g}, 1.54 \mathrm{mmol})$, appropriate arylamidoximes 1a-f $(1.00 \mathrm{mmol})$ and $\mathrm{K}_{2} \mathrm{CO}_{3}(0.12 \mathrm{~g}, 0.85 \mathrm{mmol})$ was well triturated and placed in a small glass test tube followed by irradiation in a domestic microwave oven $(100 \%$ potency, $650 \mathrm{~W})$ for 8 min and then cooled. After that, the crude product was purified by chromatography on silica gel 60 (Merck ${ }^{\circledR} 70-230$ mesh) using hexanes/EtOAc $(9: 1)$ to yield the corresponding 3-aryl-5-pentyl-1,2,4-oxadiazoles, 3a-f.

Compound 5-(pentyl)-3-(phenyl)-1,2,4-oxadiazole (3a): colorless oil, yield $80 \%$. IR (KBr) $v_{\max } 3068,2917,2848,1596,1446,1025,721 \mathrm{~cm}^{-1} .{ }^{1} \mathrm{H}$ NMR (400 MHz, CDCl $): \delta 8.10-8.07(m, 2 \mathrm{H}, \mathrm{H}), 7.52-7.45(m, 3 \mathrm{H}, \mathrm{H}$ $2.94(t, 2 \mathrm{H}, J=7.2 \mathrm{~Hz} \text {, Het-CH })_{2}, 1.89\left(q u i, J=7.2 \mathrm{~Hz}, 2 \mathrm{H}\right.$, Het- $\left.\mathrm{CH}_{2}-\mathrm{CH}_{2}\right)$, 1.46-1.37 $\left(m, 4 \mathrm{H}, 2 \times \mathrm{CH}_{2}\right), 0.93\left(t, J=7.2 \mathrm{~Hz}, 3 \mathrm{H}, \mathrm{CH}_{3}\right) .{ }^{13} \mathrm{C} \mathrm{NMR}(100$ $\mathrm{MHz},\left(\mathrm{CDCl}_{3}\right): \delta 179.7,167.9,130.7,128.4,127.0,126.7,30.8,26.3,26.0$, 21.8, 13.5. Calcd for $\mathrm{C}_{13} \mathrm{H}_{16} \mathrm{ON}_{2}: \mathrm{C}, 72.19 \% ; \mathrm{H}, 7.46 \% ; \mathrm{N}, 12.95 \%$. Found for $\mathrm{C}_{13} \mathrm{H}_{10} \mathrm{ON}_{2}$ : C, $72.08 \% ; \mathrm{H}, 7.19 \% ; \mathrm{N}, 12.65 \%$. The spectroscopic data of synthesized compound match with the reported values in the literature. ${ }^{35}$

Compound 5-(pentyl)-3-(o-tolyl)- 1,2,4-oxadiazole (3b): colorless oil, yield $80 \%$. IR $(\mathrm{KBr}) v_{\max } 3015,2962,2870,1587,1458,1028,745 \mathrm{~cm}^{-1} .{ }^{1} \mathrm{H}$ NMR (400 MHz, $\left.\mathrm{CDCl}_{3}\right): \delta 7.98\left(d, J=7.2 \mathrm{~Hz}, 1 \mathrm{H}, \mathrm{H}^{\prime}\right), 7.41-7.29(m, 3 \mathrm{H}$, $\left.\mathrm{H}_{\text {ary }}\right), 2.96\left(t, J=7.6 \mathrm{~Hz}, 2 \mathrm{H}\right.$, Het- $\left.\mathrm{CH}_{2}\right), 2.63\left(s, 3 \mathrm{H}, \mathrm{CH}_{3} \mathrm{Ph}\right), 1.89$ (qui, $J=7.6$ $\mathrm{Hz}$, Het- $\left.\mathrm{CH}_{2}-\mathrm{CH}_{2}\right) ; 1.47-1.37\left(m, 4 \mathrm{H}, 2 \times \mathrm{CH}_{2}\right) ; 0.94\left(t, J=7.6 \mathrm{~Hz}, 3 \mathrm{H}, \mathrm{CH}_{3}\right)$. ${ }^{13} \mathrm{C}$ NMR $\left(100 \mathrm{MHz},\left(\mathrm{CDCl}_{3}\right): \delta 178.9,168.8,138.1,131.3,130.4,129.9\right.$, 126.2, 125.9, 31.2, 26.5, 26.3, 22.0, 13.8. Calcd for $\mathrm{C}_{14} \mathrm{H}_{18} \mathrm{ON}_{2}: \mathrm{C}, 73.01 \%$; $7.88 \% ; \mathrm{N}, 12.16 \%$. Found for $\mathrm{C}_{14} \mathrm{H}_{18} \mathrm{ON}_{2}$ : C, $72.92 \% ; \mathrm{H}, 7.76 \%$;, $12.13 \%$.

Compound 5-(pentyl)-3-(m-tolyl)- 1,2,4-oxadiazole (3c): colorless oil, yield $85 \%$. IR $(\mathrm{KBr}) \vee \quad 3023,2968,2869,1585,1465,1021,749 \mathrm{~cm}^{-1} .{ }^{1} \mathrm{H}$ NMR (400 MHz, $\left.\mathrm{CDCl}_{3}\right): \delta$ 7.90-7.87 $\left(m, 2 \mathrm{H}, \mathrm{H}_{\text {aryl }}\right), 7.41-7.27\left(m, 2 \mathrm{H}, \mathrm{H}_{\text {ary }}\right)$, $2.94\left(\mathrm{t}, J=7.2 \mathrm{~Hz}, 2 \mathrm{H}, \mathrm{Het}-\mathrm{CH}_{2}\right), 2.42\left(\mathrm{~s}, 3 \mathrm{H}, \mathrm{CH}_{3}-\mathrm{Ph}\right), 1.88($ qui, $J=7.2$ $\mathrm{Hz}, 2 \mathrm{H}$, Het-CH $\left.-\mathrm{CH}_{2}\right) ; 1.43-1.36\left(m, 4 \mathrm{H}, 2 \times \mathrm{CH}_{2}\right) ; 0.93(t, J=7.2 \mathrm{~Hz}, 3 \mathrm{H}$, $\left.\mathrm{CH}_{3}\right) .{ }^{13} \mathrm{C} \mathrm{NMR}\left(100 \mathrm{MHz},\left(\mathrm{CDCl}_{3}\right): \delta 179.9,168.3,138.6,131.8,128.7\right.$, 127.9, 124.5, 123.2, 31.2, 26.6, 26.3, 22.1, 21.3, 13.8. Calcd for $\mathrm{C}_{14} \mathrm{H}_{18} \mathrm{ON}_{2}$ : C, $73.01 \% ; \mathrm{H}, 7.88 \%$; N, 12.16\%. Found for $\mathrm{C}_{14} \mathrm{H}_{18} \mathrm{ON}_{2}: \mathrm{C}, 72.89 \% ; \mathrm{H}, 7.79$ $\% ; \mathrm{N}, 12.09 \%$

Compound 5-(pentyl)-3-(p-tolyl)- 1,2,4-oxadiazole (3d): colorless oil, yield $81 \%$. IR $(\mathrm{KBr}) v$ 3033, 2958, 2870, 1590, 1465, 1017, $742 \mathrm{~cm}^{-1} .{ }^{1} \mathrm{H}$ NMR (400 MHz, $\left.\mathrm{CDCl}_{3}\right): \delta 7.96\left(d, J=8.4 \mathrm{~Hz}, 2 \mathrm{H}, \mathrm{H}_{\text {ary }}\right), 7.28(d, J=8.4 \mathrm{~Hz}$, $2 \mathrm{H}, \mathrm{H}), 2.93\left(t, J=7.6 \mathrm{~Hz}, 2 \mathrm{H}\right.$, Het-CH $H_{2}, 2.41(s, 3 \mathrm{H}, \mathrm{CH}-\mathrm{Ph}) ; 1.88$ (qui, $J$ $\left.=7.6 \mathrm{~Hz}, 2 \mathrm{H}, \mathrm{Het}-\mathrm{CH}_{2}-\mathrm{CH}_{2}\right) ; 1.43-1.35\left(m, 4 \mathrm{H}, 2 \mathrm{x} \mathrm{CH}_{2}\right) ; 0.92(\mathrm{t}, J=7.6 \mathrm{~Hz}$, $\left.3 \mathrm{H}, \mathrm{CH}_{3}\right) .{ }^{13} \mathrm{C} \mathrm{NMR}\left(100 \mathrm{MHz},\left(\mathrm{CDCl}_{3}\right): \delta 179.8,168.2,141.3,129.5,127.3\right.$, 124.1, 31.2, 26.6, 26.3, 22.2, 21.5, 13.8. Calcd for $\mathrm{C}_{14} \mathrm{H}_{18} \mathrm{ON}_{2}: \mathrm{C}, 73.01 \% ; \mathrm{H}$, $7.88 \% ; \mathrm{N}, 12.16 \%$. Found for $\mathrm{C}_{14} \mathrm{H}_{18} \mathrm{ON}_{2}: \mathrm{C}, 72.48 \% ; \mathrm{H}, 7.93 \% ; \mathrm{N}, 12.01 \%$.

Compound 3-(p-bromophenyl)-5-(pentyl)-1,2,4-oxadiazol (3e): Semisolid, yield $83 \%$. IR (KBr) $v_{\text {max }} 3060,2957,2859,1588,1469,1012,744$ $\mathrm{cm}^{-1}$. ${ }^{1} \mathrm{H}$ NMR $\left(400 \mathrm{MHz}, \mathrm{CDCl}_{3}\right): \delta 7.95(d, J=8.0 \mathrm{~Hz}, 2 \mathrm{H}, \mathrm{H}), 7.61(d$, $\left.J=8.0 \mathrm{~Hz}, 2 \mathrm{H}, \mathrm{H}_{\text {ary }}\right), 2.94\left(t, J=7.2 \mathrm{~Hz}, 2 \mathrm{H}\right.$, Het- $\left.\mathrm{CH}_{2}\right), 1.87(q u i, J=7.2 \mathrm{~Hz}$, $\left.2 \mathrm{H}, \mathrm{Het}-\mathrm{CH}_{2}-\mathrm{CH}_{2}\right) ; 1.43-1.36\left(m, 4 \mathrm{H}, 2 \mathrm{x} \mathrm{CH}_{2}\right) ; 0.93\left(\mathrm{t}, J=7.2 \mathrm{~Hz}, 3 \mathrm{H}, \mathrm{CH}_{3}\right)$ ${ }^{13} \mathrm{C}$ NMR $\left(100 \mathrm{MHz},\left(\mathrm{CDCl}_{3}\right): \delta 180.3,167.5,132.1,128.8,125.9,125.5\right.$, 31.1, 26.6, 26.3, 22.1, 13.8. Calcd for $\mathrm{C}_{13} \mathrm{H}_{15} \mathrm{BrON}_{2}$ : C, 52.90\%; $\mathrm{H}, 5.12 \%$; N, 9.49\%. Found for $\mathrm{C}_{13} \mathrm{H}_{15} \mathrm{BrON}_{2}$ : C, $52.82 \% ; \mathrm{H}, 5.08 \%$; N, 9.23\%. The spectroscopic data of synthesized compound match with the reported values in the literature..$^{35}$

Compound 3-(p-chlorophenyl)-5-(pentyl)-1,2,4-oxadiazol (3f): Semisolid, yield 85\%. IR (KBr) v 3070, 2957, 2871, 1594, 1446, 1015, 72 $\mathrm{cm}^{-1}$. ${ }^{1} \mathrm{H}$ NMR $\left(400 \mathrm{MHz}, \mathrm{CDCl}_{3}\right)^{\max } \delta 8.02\left(d, J=8.4 \mathrm{~Hz}, 2 \mathrm{H}, \mathrm{H}_{\text {ary }}\right), 7.46(d, J$ $=8.4 \mathrm{~Hz}, 2 \mathrm{H}, \mathrm{H}), 2.94(t, J=7.2 \mathrm{~Hz}, 2 \mathrm{H}$, Het-CH, $), 1.88(q u i, J=7.2 \mathrm{~Hz}, 2 \mathrm{H}$, Het- $\left.\mathrm{CH}_{2}-\mathrm{CH}_{2}\right) ; 1.44-1.36\left(m, 4 \mathrm{H}, 2 \times \mathrm{CH}_{2}\right) ; 0.93\left(t, J=7.2 \mathrm{~Hz}, 3 \mathrm{H}, \mathrm{CH}_{3}\right) \cdot{ }^{13} \mathrm{C}$ NMR $\left(100 \mathrm{MHz},\left(\mathrm{CDCl}_{3}\right): \delta 180.6,167.8,137.5,129.9,129.4,129.0,125.8\right.$, 31.5, 26.9, 26.6, 22.5, 14.1. Calcd for $\mathrm{C}_{13} \mathrm{H}_{15} \mathrm{ClON}_{2}: \mathrm{C}, 62.28 \% ; \mathrm{H}, 6.03 \%$; $11.17 \%$. Found for $\mathrm{C}_{13} \mathrm{H}_{15} \mathrm{ClON}_{2}$ : C, $62.41 \% ; \mathrm{H}, 6.13 \%$; N, $11.29 \%$.

\section{Pharmacology}

Cytotoxicity assay

The antiproliferative activities 3-aryl-5-pentyl-1,2,4-oxadiazoles 3a-f were evaluated in the following human cancer cells lines: NCI H292 (lung carcinoma), HL-60 (pro-myelocytic leukemia) and HT29 (colon carcinoma) provided by the Rio de Janeiro Cell Bank (RJ-Brazil). All cancer cells were maintained in RPMI 1640 medium and DMEN supplemented with $10 \%$ fetal bovine serum, $2 \mathrm{mM}$ glutamine, $100 \mathrm{U} / \mathrm{mL}$ penicillin, $100 \mu \mathrm{g} / \mathrm{mL}$ streptomycin at $37^{\circ} \mathrm{C}$ with $5 \% \mathrm{CO}_{2}$. The cytotoxicity of all compounds was tested using the 3-(4,5-dimethyl-2-thiazolyl)-2,5-diphenyl- $2 H$ tetrazolium bromide (MTT) (Sigma Aldrich Co., St. Louis, MO, USA) reduction assay. For all experiments, tumor cells were plated in $96-$ well plates $\left(10^{5} \mathrm{cells} / \mathrm{mL}\right.$ for adherent cells or $3 \times 10^{5}$ cells $/ \mathrm{mL}$ for Leukemia). Tested Compounds $(0.1-25 \mu \mathrm{g} / \mathrm{mL})$ dissolved in DMSO $1 \%$ were added to each well and incubated for $72 \mathrm{~h}$. Control groups received the same amount of DMSO. After $69 \mathrm{~h}$ of treatment $25 \mu \mathrm{L}$ of MTT $(5 \mathrm{mg} / \mathrm{mL})$ was added, three hours later, the MTT formazan product was dissolved in $100 \mu \mathrm{L}$ of DMSO, and absorbance was measured at $595 \mathrm{~nm}$ in plate spectrophotometer. $\mathrm{The}^{\mathrm{IC}} \mathrm{C}_{50}$ values and their $95 \%$ confidence intervals for two different experiments were obtained by nonlinear regression using the Graphpad Prism program (Intuitive Software for Science, San Diego, CA).

\section{RESULTS AND DISCUSSION}

In a typical experimental procedure, the ester or acid was refluxed or heated to a certain predetermined temperature with the desired amount of alcohol in the presence of sulfuric acid. The reaction was monitored by TLC and after completion, the excess alcohol was removed and the residue was extracted with ether. The ether extract, after being washed with sodium bicarbonate and subsequently with distilled water, was evaporated to furnish the product with $78 \%$ yield.

Arylamidoximes 1a-f were synthesized in excellent yields (85-92\%) using a reaction of arylnitriles with hydroxylamine hydrochloride in the presence of base under ultrasonic irradiation. ${ }^{36}$

The 3-aryl-5-pentyl-1,2,4-oxadiazoles 3a-f were synthesized by the treatment of arylamidoxime 1a-f with ethyl hexanoate $\mathbf{2}$ for 8 minutes under microwave irradiation using carbonate as base in solvent-free conditions (Scheme 1). The solvent-free conditions likely contributed to the high efficiency of this reaction in two ways: driving the reaction toward the desired oxadiazole product by removing other volatile products and favored entropy effect by achieving high concentration of arylamidoxime reactants. The heterocycles 3a-f were obtained in good yields after purification (80-85\%).

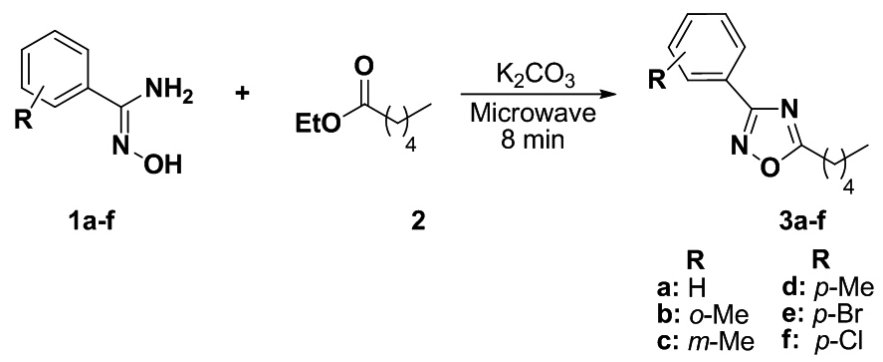

Scheme 1. Synthesis 3-(aryl)-5-(n-penthyl)-1,2,4-oxadiazoles 3a-f.

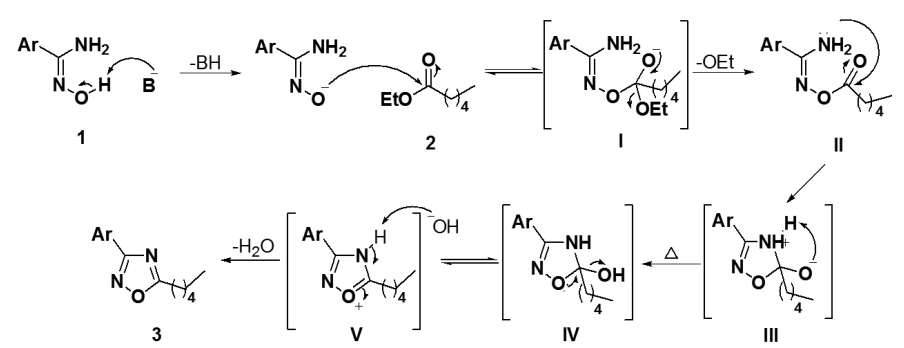

Scheme 2. Proposal for mechanism of formation of 3-(aryl)-5-(n-penthyl)1,2,4-oxadiazoles 3 .

The scope and generality of this process is illustrated by a series of seven compounds and the results are presented in Table 1. 
Table 1. Synthesis of 3-aryl-5-penthyl-1,2,4-oxadiazoles 3a-f under microwave irradiation.

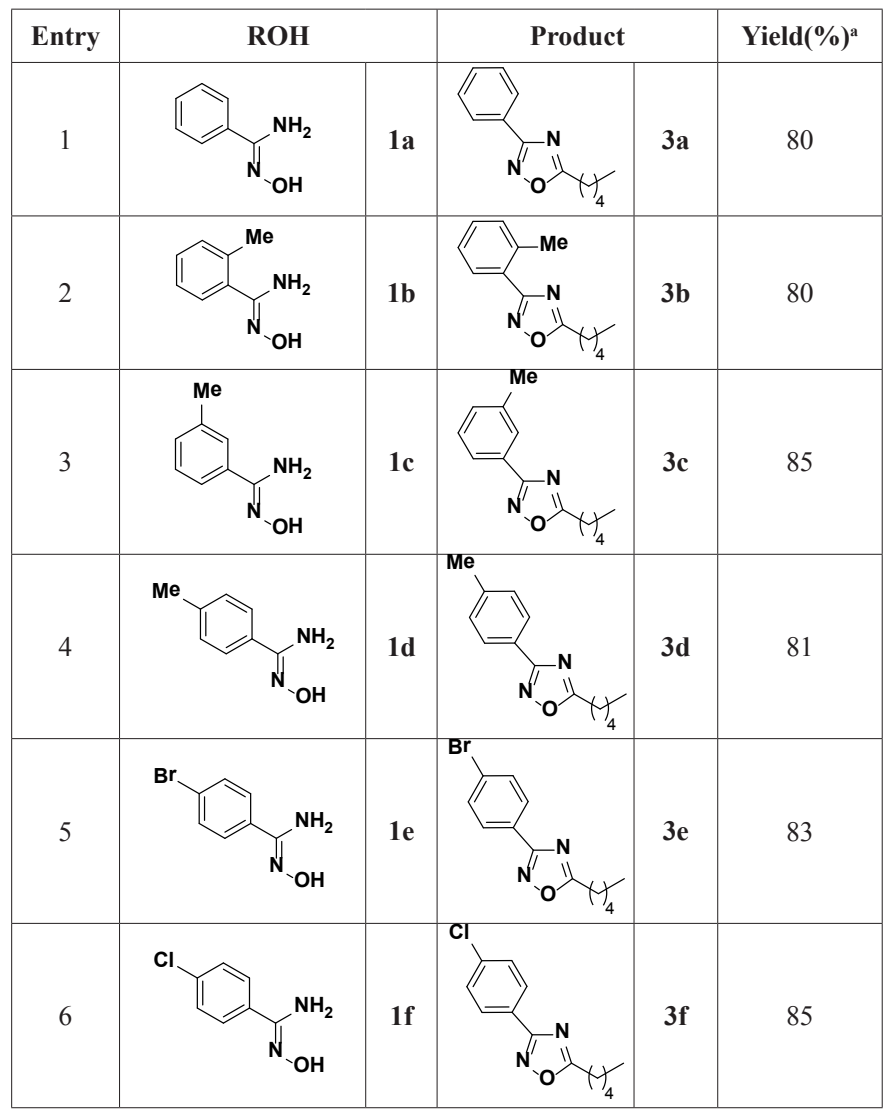

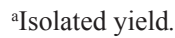

A proposed reaction mechanism for the formation the 1,2,4-oxadiazole is outlined in scheme 2 . Initially the removal of the acidic ${ }^{37}$ proton of $\mathbf{1}$ with a suitable base create an anion at the oxygen atom which attacks the carbonyl carbon of $\mathbf{2}$ to furnish an unstable tetrahedral species I with subsequent loss of ethanol to give II. Then, this intermediate is cyclized to furnish III, suffering elimination of water by heating (intermediate $\mathbf{I V}$ and $\mathbf{V}$ ) to produce 1,2,4-oxadiazole 3 .

The compounds were characterized by IR, ${ }^{1} \mathrm{H}$ and ${ }^{13} \mathrm{C}$ NMR spectroscopy and elemental analysis. For instance, IR absorptions at $1634(\mathrm{C}=\mathrm{N})$ and 1446 $\mathrm{cm}^{-1}(\mathrm{C}-\mathrm{O})$ were obtained for 5-pentyl-3-phenyl-1,2,4-oxadiazole, 3a.

The $400 \mathrm{MHz}{ }^{1} \mathrm{H}$ NMR spectra of compounds 3a-f showed a triplet between 0.94-0.92 ppm for the terminal methyl groups $(J=7.6-7.2 \mathrm{~Hz})$ and a triplet between 2.96-2.93 ppm for methylene group $(J=7.6-7.2 \mathrm{~Hz})$. Other signals were observed at appropriate places. The spectrum showed two doublets of doublet at signals for NCO and NCN in ${ }^{13} \mathrm{C}$ NMR at 179.7 and $167.9 \mathrm{ppm}$ further identify oxadiazole moiety in $\mathbf{3 a}$.

\section{Pharmacology}

The antiproliferative activity of the compounds $\mathbf{3 a - f}$ was evaluated using an MTT assay ${ }^{38}$ against three human cell lines: NCI H292 (lung carcinoma), HL-60 (pro-myelocytic leukemia) and HT29 (colon carcinoma). In this way, initially the six compounds were first screened at $25 \mu \mathrm{g} / \mathrm{mL}$ initial concentration and the compounds that exhibited inhibition up $90 \%$ were utilized to determine the $\mathrm{IC}_{50}$ concentration values of compounds studied, as shown in Table 2.

According to Table 2 the compounds $\mathbf{3 c}, \mathbf{3 e}$ and $\mathbf{3 f}$ exhibited moderate cytotoxicity activity against HL-60 cancer cell lines with $\mathrm{IC}_{50}$ values of 42.1, 19.0 and $28 \mu \mathrm{M}$, respectively. Possibly the explanation of this cytotoxic activity only in HL-60 cancer cell lines is due to this type of cell line be sensible to oxidative stress therefore present low level of antioxidant defense. . $^{39,40}$

Compounds 3a, 3b and 3d did not show antiproliferative activity for three human cell lines studied, however, this initial study demonstrates the potential of this class of compounds for this particular activity since the compounds $\mathbf{3 c}$, 3e and $\mathbf{3 f}$ exhibited moderate activity.

Table 2. $\mathrm{IC}_{50}$ values $\mu \mathrm{M}$ for compounds 3a-f. 1a-f<smiles>[R][X]c1ccccc1/C(N)=N/O</smiles>

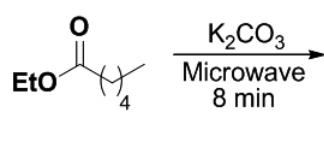

2

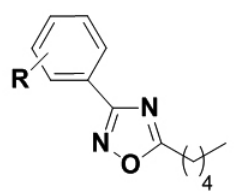

3a-f

\begin{tabular}{|c|c|c|c|}
\hline Compound & HL-60 & NCI-H292 & HT29 \\
\hline 3a & $>115.6$ & $>115.6$ & $>115.6$ \\
\hline 3b & $>108.6$ & $>108.6$ & $>108.6$ \\
\hline 3c & 42.1 & $>108.6$ & $>108.6$ \\
\hline 3d & $>108.6$ & $>108.6$ & $>108.6$ \\
\hline 3e & 19.0 & $>85$ & $>85$ \\
\hline 3f & 28.0 & $>100$ & $>100$ \\
\hline DOX $^{\mathbf{a}}$ & 0.04 & 0.4 & 0.8 \\
\hline
\end{tabular}

${ }^{\mathrm{a}}$ Doxorubicin (DOX) was the positive control.

\section{CONCLUSION}

In summary, we have described the simple and rapid preparation of 1,2,4-oxadiazoles in under microwave irradiation. The final products were obtained in short times and with good yields (80-85\%). The compounds 3a-f were tested against three human cell lines where only of compounds $\mathbf{3 c}, \mathbf{3 e}$ and 3 exhibited moderate antiproliferative activity against HL-60 cancer cell lines with $\mathrm{IC}_{50}$ values of $42.1,19.0$ and $28 \mu \mathrm{M}$, respectively. Additional reactions conducting to new structures are required because the synthesis of related oxadiazole structures can lead to better cytotoxic activities.

\section{ACKNOWLEDGMENTS}

The authors are grateful to the Brazilian National Research Council (CNPq), FACEPE APQ 1257-106/10.” and CAPES for financial support.

\section{REFERENCES}

1. M. Ispikondi, M. Amvrazis, C. Kontogiorgis, A. E. Koumbis, K. E. Litinas, D. Hadjipavlon-Litina, K. C. Fylaktakidou, Eur. J. Med. Chem. 45, $5635(2010)$.

2. J. M. Dos Santos Filho, J. G. De Lima, L. F. C. C. Leite, J. Heterocyclic Chem. 46, 722 (2009).

3. N. M. M. Bezerra, S. P. De Oliveira, R. M. Srivastava, J. R. Da Silva, II Farmaco 60, 955 (2005).

4. A. A. Gakh, A. V. Sosnov, M. Krasavin, T. L. Nguyen, E. Hamel, Bioorg. Med. Chem. Lett. 23, 1262 (2013).

5. J. V. Dos Anjos, R. A. W. Neves Filho, S. C. Do Nascimento, R. M. Srivastava, S. J. De Melo, D. Sinou, Eur. J. Med. Chem. 44, 3571 (2009).

6. J. N. Sangshetti, D. B. Shinde, Eur. J. Med. Chem. 46, 1040 (2011).

7. H. A. Rajapakse, H. Zhu, M. B. Young, B. T. Mott, Tetrahedron Lett. 47, 4827 (2006).

8. G. N. Vazquez, G. M. M. Salinas, Z. V. D. Fajardo, J. V. Villarreal, S. E. Soto, F. G. Salazar, E. H. Nunes, S. S. Fernandez, Bioorg. Med. Chem. 15, 5502 (2007).

9. D. M. Cottrell, J. Capers, M. M. Salem, K. D. L. Fradley, S. L. Croft, K. A. Werbovetz, Bioorg. Med. Chem. 12, 2815 (2004).

10. A. C. L. Leite, R. F. Vieira, A. R. de Faria, A. G. Wanderley, P. Afiatpour, E. C. P. A. Ximenes, R. M. Srivastava, C. F. de Oliveira, M. V. Medeiros, E. Antunes, D. J. Brondani, II Farmaco 55, 719 (2000).

11. J. Rudolph, H. Theis, R. Hanke, R. Endermann, L. Johannsen, F. U. Geschke, U. J. Med. Chem. 44, 619 (2001).

12. K. Ohmoto, T. Yamamoto, T. Horiuchi, H. Imanishi, Y. Odagaki, K. Kawabata, T. Sekioka, Y. Hirota, S. Matsuoka, H. Nakai, M. Toda, J. C. Cheronis, L. W. Spruce, A. Gyorkos, M. Wieczorek, J. Med. Chem. 43, 4927 (2000). 
13. M. Benltifa, S. Vidal, B. Fenet, M. Msaddek, P. G. Goekjian, J. P. Praly, A. Brunyánszki, T. Docsa, P. Gergely, Eur. J. Org. Chem. 4242 (2006).

14. H. Z. Zhang, S. Kasibhatla, J. Kuemmerle, W. Kemnitzer, K. OllisMason, L. Qiu, C. Crogan-Grundy, B. Tseng, J. Drewe, S. X. Cai, J. Med. Chem. 48, 5215 (2005).

15. D. Kumar, G. Patel, E. O. Johnson, K. Shah, Bioorg. Med. Chem. Lett. 19, 2739 (2009).

16. R. A. W. Neves Filho, C. A. Silva, C. S. B. Silva, V. P. Brustein, D. M. A. F. Navarro, F. A. B. Santos, L. C. Alves, M. G. S. Cavalcanti, R. M. Srivstava, M. G. Carneiro-Da-Cunha, Chem. Pharm. Bull. 57, 819 (2009).

17. S. Chiou, H. J. Shine, J. Heterocyclic Chem. 26, 125 (1989).

18. A. R. Gangloff, J. Litvak, E. J. Shelton, D. Sperandio, V. R. Wang, K. D. Rice, Tetrahedron Lett. 42, 1441 (2001) and references cited therein.

19. A. L. Braga, D. S. Lüdtke, E. E. Alberto, L. Dornelles, W. A. S. Filho, V. A. Corbellini, D. M. Rosa, R. S. Schwab, Synthesis 10, 1589 (2004).

20. G. B. Liang, D. D. Feng, Tetrahedron Lett. 37, 6627 (1996).

21. S. Borg, G. Estenne-Bouhtou, K. Luthman, I. Csöregh, W. Hesselink, U. Hacksell, J. Org. Chem. 60, 3112 (1995)

22. Rice, K. D.; Nuss, J. M. Bioorg. Med. Chem. Lett. 11, 753 (2001).

23. L. Luche, Synthetic Organic Sonochemistry, Plenum Press, New York, (1998).

24. R. M. Srivastava, R. A. W. N. Filho, C. A. Silva, A. Bortoluzzi, Ultrason. Sonochem. 16, 737 (2009).

25. I. Mohammadpoor-Baltork, M. Moghadam, S. Tangestaninejad, V. Mirkhani, Z. Eskandari, Ultrason. Sonochem. 17, 857 (2010).

26. W. R. Dolbier Jr, C. R. Burkholder, M. MeÂdebielle, J. Fluorine Chem. 95, 127 (1999).
27. J. K. Augustine, V. Akabote, S. G. Hegde, P. Alagarsamy, J. Org. Chem. 74, 5640 (2009)

28. M. Adib, A. H. Jahromi, N. Tavoosi, M. Mahdavi, H. R. Bijanzadeh, Tetrahedron Lett. 47, 2965 (2006).

29. A. Porcheddu, R. Cadoni, L. De Luca, Org. Biomol. Chem. 9, 7539 (2011).

30. J. J. R de Freitas, J. C. R. Freitas, L. P. da Silva, J. R. F. Filho, G. Y. V. Kimura, R. M. Srivastava, Tetrahedron Lett. 48, 6195 (2007).

31. R. A. W. Neves Filho, R. M. Srivastava, Molecules 11, 318 (2006).

32. P. Lidstrom, J. Tierney, B. Wathey, J. Westman, Tetrahedron 57, 9225 (2001).

33. D. H. Boschelli, D. T. Connor, D. A. Bornemeier, R. D. Dyer, J. A. Kennedy, P. J. Kuipers, G. C. Okonkwo, D. J. Schrier, C. D. Wright, J. Med. Chem., 36, 1802 (1993).

34. F. Alonso, P. Riente, M. Yus, Tetrahedron 65, 10637 (2009).

35. B. Kaboudin, L. Malekzadeh, Tetrahedron Lett. 52, 6424 (2011).

36. C. J. P. Barros, J. J. R; de Freitas, R. N. de Oliveira, J. R. F. Filho, J. Chil. Chem. Soc. 56, 721 (2011).

37. R. M. Srivastava, I. M. Brinn, J. O. Machuca-Herrera, H. B. Faria, G. B. Carpenter, D. Andrade, C. G. Venkatesh, L. P. F. de Morais, J. Mol. Struct. 406, 159 (1997).

38. I. B. Vasconcelos, T. G. da Silva, G. G. G. Militão, T. A. Soares, N. M. Rodrigues, M. O. Rodrigues, N. B. da Costa, R. O. Freire, S. A. Junior, RSC Adv. 2, 9437 (2012).

39. Y. Chan, S. Shiah, M. Don, M. Kuo, Free Radical Biol. Med. 24, 660 (1998).

40. C. D. Buarque, G. C. G. Militão, D. J. B. Lima, L. V. Costa-Lotufo, C. Pessoa, M. O. Moraes, E. F. Cunha-Junior, E. C. Torres-Santos, C. D. Netto, P. R.R. Costa, Bioorg. Med. Chem. 19, 6885 (2011). 